\title{
LEARNING POLITENESS IN INTERVIEWS USING ROLE PLAY STRATEGIES
}

\author{
Susanti Sri Purnama \\ Universitas Suryakancana Cianjur \\ susanpurnama30@gmail.com
}

\begin{abstract}
This article describes the effectiveness of learning politeness speak by using the role playing strategy of grade VIII B MTs Islamiyah Sayang students. The method used in the research is the experimental method with the object of research class VIII students as many as 35 people. The result showed $61,76 \%$ of students got the highest score in the final test in politeness of speech when doing interview using role playing strategy that is 91 with the number of students who got 1 person, the students who get the value of 90 that is 2 people, the students who get the value 89 seb sebasar 2 people, students who score 87 as much as 2 people, students who get 86 points as much as 1 person, students who get the value of 85 as many as 3 people, students who get the value of 84 as 3 students who get the value of 81 as 3 people, students who get a score of 80 as 1 person, students who get the value of 79 as many as 2 people, students who scored 77 as many as 2 people, students who score 76 as many as 1 person, students who score 75 as many as 2 people, and students who score 73 as many as 1 person. Judging from the average percentage of capabilities reaching $82.33 \%$ of final test research considers effective role-playing strategies used in speech decency learning in interviews.
\end{abstract}

Keywords: decency, interview, role play.

\section{PENDAHULUAN}

Berbicara adalah suatu keterampilan berbahasa yang berkembang pada kehidupan anak yang hanya didahului oleh keterampilan menyimak dan pada masa tersebutlah kemampuan berbicara atau berujar dipelajari (Tarigan, 2008:3). Kemudian, ketika berbicara atau berkomunikasi dalam suatu masyarakat peranan sopan santun sangat penting, karena apabila berkomunikasi tidak ada sopan santun, akan menimbulkan konflik. Oleh karena itu, sopan santun dalam bebicara penting untuk diketahui. Terkadang orang bisa melakukan komunikasi tetapi dia belum paham tentang bagaimana komunikasi yang baik itu dilakukan, masih banyak sebagian masyarakat yang belum mengerti tentang berkomunikasi dengan sopan.

Sopan santun adalah sikap seseorang terhadap apa yang dilihat, apa yang dirasakan, dan dalam situasi ataupun kondisi apapun. Sikap santun yaitu baik, hormat, tersenyum dan taat kepada suatu aturan. Sikap sopan santun yang benar ialah lebih menonjolkan pribadi yang baik dan menghormati siapa saja. Dari tutur bicara orang bisa melihat melihat kesopanan seseorang.

Nadar (2009:251) mengungkapkan "Kesopanan berbahasa adalah kesantunan berbahasa yang diambil penutur dalam rangka meminimalisir atau mengurangi derajat perasaan tidak senang atau sakit hati sebagai akibat tuturan yang diungkapkan oleh seorang penutur".

Seseorang tidak akan dapat berbicara dengan baik dan benar tanpa mempelajari bahasa itu sendiri. Oleh karena itu, pembelajaran bahasa Indonesia dijadikan bahasa pengantar di sekolah-sekolah. Diharapkan para pemakai bahasa Indonesia dapat berkomunikasi dengan bahasa Indonesia yang 
baik dan memperhatikan kesopanan berbicara.

Bermain peran merupakan salah satu metode pembelajaran yang melibatkan siswa secara aktif. Aktivitas siswa sangat diharapkan dalam setiap proses pembelajaran. Keterlibatan siswa secara aktif dalam kegiatan pembelajaran akan sangat membantu keberhasilan kegiatan pembelajaran itu. Atas dasar pemikiran itu, metode bermain peran tergolong akan efektif diterapkan dalam kegiatan pembelajaran peningkatan kesopanan siswa dalam berbicara. Itulah sebabnya dalam penelitian dilakukan uji coba metode bermain peran dalam upaya meningkatkan kesopanan siswa dalam berbicara.

Selain itu, perlu pula dilakukan telaah untuk mengetahui faktor-faktor kesulitan siswa ketika berbicara dengan sopan, dan memperbaiki agar siswa mampu berkomunikasi dengan sopan dengan lawan tuturnya. Jika hal itu tidak dilakukan siswa akan kesulitan untuk berbicara dengan baik dan sopan dengan lawan tuturnya.

Sekolah merupakan tempat untuk mempelajari berbagai ilmu pengetahuan yang termasuk di dalamnya mempelajari bahasa Indonesia. Diharapkan setelah belajar bahasa Indonesia, siswa sebagai pengguna bahasa Indonesia mampu berbicara dengan bahasa Indonesia yang baik dan benar dan mampu meningkatkan kesopanan berbicara. Dengan demikian penggunaan bahasa Indonesia dan kesopanan berbicara siswa akan lebih meningkat.

Menurut Nazir (67:1988) "Wawancara adalah proses memperoleh keterangan untuk tujuan penelitian dengan cara tanya jawab sambil bertatap muka antara si penanya atau pewawancara dengan si penjawab atau responden dengan menggunakan alat yang dinamakan interview guide (panduan wawancara)". Walaupun wawancara adalah proses percakapan yang berbentuk tanya jawab dengan tatap muka, wawancara adalah suatau proses pengumpulan data untuk suatu penelitian. Beberapa hal dapat membedakan wawancara dengan percakapan sehari-hari adalah antara lain:

a. Pewawancara dan responden biasanya belum saling kenal sebelumnya.

b. Responden selalu menjawab pertanyaan.

c. Pewawancara selalu bertanya.

d. Pewawancara tidak menjuruskan pertanyaan kepada suatu jawaban, tetapi harus selalu bersifat netral.

Pertanyaan yang ditanyakan mengikuti panduan yang telah dibuat sebelumnya. Pertanyaan panduan ini dinamakan interview guide.

Bermain peran merupakan salah satu metode pembelajaran yang melibatkan siswa secara aktif. Aktivitas siswa sangat diharapkan dalam setiap proses pembelajaran. Keterlibatan siswa secara aktif dalam kegiatan pembelajaran akan sangat membantu keberhasilan kegiatan pembelajaran itu. Atas dasar pemikiran itu, metode bermain peran tergolong efektif diterapkan dalam kegiatan pembelajaran peningkatan kesopanan siswa dalam berbicara. Itulah sebabnya dalam penelitian dilakukan uji coba metode bermain peran dalam upaya meningkatkan kesopanan siswa dalam berbicara.

Adapun strategi pembelajaran yang digunakan dalam penelitian adalah strategi bermain peran. strategi pembelajaran bermain peran merupakan suatu metode pembelajaran yang meminta orang-orang yang terlibat dalam metode ini menganggap bahwa dirinya sebagai orang lain dengan tujuan untuk mempelajari bagaimana orang lain bertindak dan dapat merasakannya.

Diharapkan pembelajaran ini bisa menjadi solusi bagi pilihan pembelajaran kesopanan berbicara dalam wawancara dan bisa mengaplikasikan secara langsung apa yang sudah dipelajari.

\section{METODE}

Metode yang digunakan dalam penelitian adalah eksperimen. Metode 
eksperimen berarti metode percobaan untuk mempelajari pengaruh dari variabel tertentu terhadap variabel yang lain, melalui uji coba dalam kondisi yang khusus yang sengaja diciptakan (Fathoni 2006:99). Metode penelitian yang ditempuh melalui kegiatan uji coba pembelajaran kesopanan berbicara dengan menggunakan teknik bermain peran. Desain eksperimental yang digunakan dalam penelitian ini adalah desain pretest dan posttest.

Sesuai dengan desain tersebut, pelaksanaan uju coba dilakukan dengan langkahlangkah berikut.

1) Menentukan sampel sebanyak satu kelas dengan menggunakan teknik pengambilan random sampel.

2) Sebelum pelaksanaan pembelajaran diadakan tes awal untuk mengetahui kemampuan awal siswa dalam pembelajaran kesopanan berbicara dalam wawancara.

3) Melakukan pembelajaran menggunakan strategi bermain peran mengenai kesopanan berbicara dalam wawancara.

4) Melakukan tes akhir untuk mengetahui kemampuan siswa dalam kesopanan berbicara dalam wawancara.

Teknik penelitian yang digunakan teknik performentes dan observasi. Pada penelitian ini tes dilakuakn sebanyak dua kali, yaitu tes awal sebelum melakukan pembelajaran dan tes akhir yang dilakukan setelah pembelajaran, tujuannya diadakan tes tersebut untuk mengukur kemampuan siswa dalam kesoapanan berbicara dalam melakukan wawancara dengan menggunkaan stategi bermain peran, dengan aspek yang dinilai yaitu tekanan, intonasi, nada dan jeda, diksi (pilihan kata), struktur kalimat, kesopanan dan sikap berbicara, kelancaran bahasa, pandangan, ketepatan sasaran pembicaraan, isi wawancara.

\section{HASIL DAN PEMBAHASAN}

\section{Hasil}

Pembelajaran yang dilakukan dalam penelitian ini yaitu pembelajaran kesopanan berbicara dengan menggunakan strategi bermain peran. Pelaksanaan pembelajaran dilakukan langsung oleh peneliti, yang bertujuan untuk melihat efektifitas strategi bermain peran dalam pembelajaran kesopaann berbicara ketika melakukan wawancara.

Langkah-langkah proses belajar mengajar dilakukan sesuai dengan langkah-langkah yang terdapat dalam strategi bermain peran, dikemas dalam tiga bagian yakni kegiatan awal, kegiatan inti, dan kegiatan akhir.

Kegiatan awal ini yakni guru mengucapkan salam ketika masuk kelas, setelah itu guru mempersilahkan ketua kelas memimpin doa sebelum pembelajaran di mulai, lalu guru mendata kehadiran siswa untuk menegetahui jumlah siswa yang hadir. Dengan demikian diperoleh 3 siswa dari jumlah 40 siswa. Kemudian guru menyampaikan standar kompetensi, kompetensi dasar, indikator dan tujuan pembelajaran yang harus siswa ketahui.

Kegiatan inti, hal yang dilakukan dalam kegiatan inti yakni:

Guru memulai pembelajaran yang akan disampaikan kepada siswa yakni menegnai pembelajaran kesopanan berbicara ketika melakukan wawancara dengan menggunkan strategi bermain peran. Guru memberikan materi mengenai kesopanan, berbicara yang sesuai dengan aturan baik itu formal maupun nonformal, kemudian memberikan materi mengenai wawancara secara keseluruhan dan materi tentang strategi bermain peran.

Guru memberikan lembar tes kepada siswa untuk membuat teks wawancara sesuai dengan aturan yang di berikan. Guru memilih peran siapa yang akan menjadi narasumber 
dan siapa yang akan menjadi pewawancara kemudian siswa memainkan peran secara berkelompok yaitu dua orang, satu orang sebagai pewawancara dan satu orang sebagai narasumber.

Guru mengarahkan siswa untuk memperhatikan siswa lain yang sedang praktek wawancara dan menilai temannya yang lain dengan aturan yang sesuai yakni berwawancara dengan memperhatikan aspek yang di nilai yakni aspek tekanan, nada, jeda, diksi, struktur kalimat, kesopanan berbicara, kelancaran berbahasa, pandangan, ketepatan sasaran pembicaraan, dan isi wawancara.

Pelaksanaan strategi bermain peran dalam wawancara ini dilakukan 15 adegan dan siswa lain memperhatikan dengan penuh perhatian sebagai apresiator sebagai contoh dan tidak melakukan kesalahan ketika melakukan adegan wawancara berikutnya. Guru menilai siswa yang sedang melakukan adegan sampe dengan selesai. Setelah kegiatan bermain peran selesai guru dan siswa melakukan diskusi tentang kesopanan berbicara ketika wawancara baik itu dengan guru teman orang tua dan orang yang baru di kenal.

Pada kegiatan akhir guru malakukan refleksi terhadap kegiatan yang sudah dilakukan, siswa menjawab pertanyaan guru seputar pembelajaran yang sudah dilakukan, terakhir guru menutup pembelajaran dengan mengucapkan hamdalah dan salam.

Persiapan pembelajaran kesopanan berbicara dengan menggunakan strategi bermain peran pada siswa kelas VIII MTs Islamiyah Sayang yaitu guru mempersiapkan prangkat pembelajaran mulai dari RPP dan Silabus.

Nilai keseluruhan siswa sebelum menggunkan strategi bermain peran yaitu sebesar 1.853 dan di rata-ratakan menjadi 61,76. Untuk aspek no 1 mengenai tekanan yang dilakukan pada saat berbicara ketika wawancara jumlah nilai keseluruhan 186 dan setelah di rata-ratakan sebesar 6,2. Nilai yang tertinggi dari no 1 yaitu 8 sebanyak 1 orang, siswa yang mendapatkan nilai sedang yaitu 7 sebanyak 9 orang, dan nilai yang paling kecil yaitu 5 sebanyak 5 orang.

Untuk aspek no 2 yaitu nada yang dilakukan pada saat berbicara ketika wawancara jumlah nilai keseluruhan yaitu 186 dan setelah di rata-ratakan sebesar 6,2. Nilai yang tertinggi dari no 2 yaitu 7 sebanyak 9 orang. Siswa yang mendapatkan nilai sedang yaitu 6 sebanyak 18 orang, dan nilai terendah yaitu 5 sebanyak 3 orang.

Untuk aspek no 3 yaitu jeda yang dilakukan pada saat berbicara ketika wawancara jumlah nilai keseluruhan sebesar 189 dan dirata-ratakan sebesar 6,3. Nilai yang tertinggi dari no 3 yaitu 7 sebanyak 12 orang. Siswa yang mendapatkan nilai sedang yaitu 6 sebanyak 15 orang, dan yang mendapatkan nilai terendah yaitu 5 sebanyak 3 orang.

Untuk aspek no 4 yaitu diksi yang digunakan pada saat berbicara ketika wawancara jumlah nilai keseluruhan sebesar 198 dan dirata-ratakan menjadi 6,6. Nilai yang tertinggi yaitu 8 sebanyak 1 orang. Siswa yang mendapatkan nilai sedang yaitu 7 sebanyak 18 orang dan yang mendapatkan nilai terendah yaitu 5 sebanyak 2 orang.

Untuk aspek no 5 yaitu struktur kalimat yang digunakan pada saat wawancara jumlah nilai keseluruhan sebesar 199 dan dirataratakan sebesar 6,46. Nilai yang tertinggi yaitu 7 sebanyak 15. Siswa yang mendapatkan nilai sedang yaitu 6 sebanyak 14 orang dan yang mendapatkan niali terendah yaitu 5 sebanyak 1 orang.

Untuk aspek no 6 yaitu kesopanan yang dilakukan pada saat wawancara jumlah nilai keseluruhan sebesar 187 dan di rata-ratakan sebesar 6,23. Siswa yang mendapatkan nilai tertinggi yaitu sebesar 7 sebanyak 11 orang. Siswa yang mendapatkan nilai sedang yaitu 6 sebanyak 15 orang, dan yang mendapatkan niali terrendah yaitu 5 sebanyak 4 orang . 
Untuk aspek no 7 yaitu sikap yang dilakukan pada saat wawancara jumlah niali keseluruhan yaitu 189 dan dirata-ratakan sebesar 6,3. Siswa yang mendapatkan nilai tertinggi yaitu 7 sebanyak 15. Siswa yang mendapatkan nilai sedang yaitu 6 sebanyak 9 orang dan yang mendapatkan nilai terendah yaitu 5 sebanyak 6 orang.

Untuk aspek no 8 yaitu pandangan yang dilakukan pada saat wawancara jumlah nilainya secara keseluruhan sebesar 188 dan dirata-ratakan sebesar 6,26. Siswa yang mendapatkan nilai tertinggi yaitu 8 sebanyak 1 orang. Siswa yang mendapatkan niali sedang yaitu 7 sebanyak 10 orang dan yang mendapatkan niali terendah yaitu 5 sebanyak 4.

Untuk aspek no 9 yaitu ketepatan sasaran yang dilakukan pada saat wawancara jumlah nilainya secara keseluruhan sebesar 185 dan dirata-ratakan sebesar 6,16. Siswa yang mendapatkan nilai tertinggi yaitu 7 sebanyak 10 orang. Siswa yang mendapatkan niali sedang yaitu 6 sebanyak 15 orang dan yang mendapatkan niali terendah yaitu 5 sebanyak 5 orang.

Untuk aspek no 10 yaitu isi wawancara jumlah nilainya secara keseluruhan sebesar 182 dan dirata-ratakan sebesar 6,06. Siswa yang mendapatkan nilai tertinggi yaitu 7 yaitu sebanyak 7. Siswa yang mendapatkan niali sedang yaitu 6 sebanyak 18 orang dan yang mendapatkan niali terendah yaitu 5 ebanyak 5 orang.

Nilai paling tinggi pada tes awal dalm kesopanan berbicara ketika melakukan wawancara yaitu 72 dengan jumlah siswa yang memperolehnya 1 orang, siswa yang memperoleh nilai 68 yaitu sebanyak 2 orang, siswa yang memperoleh nilai 67 sebanya 2 orang, siswa yang memperoleh nilai 66 sebanyak 4 orang, siswa yang memperoleh nilai 65 sebanyak 4 orang, siswa yang memperoleh nilai 63 sebanyak 4 orang, siswa yang memperoleh nilai 61 sebanyak 2 orang siswa yang memperoleh nilai 60 sebanyak 2 orang, siswa yang memperoleh nilai 59 sebanyak 1 orang, siswa yang memperoleh nilai 57 sebanyak 3 orang, siswa yang memperoleh nilai 56 sebanyak 1 orang, siswa yang memperoleh nilai 54 sebanyak 1 orang, siswa yang memperoleh nilai 52 sebanyak 1 orang, dan siswa yang memperoleh nilai 51 sebanyak 1 orang.

Kemudian pada tes akhir dengan menggunakan strategi bermain peran pada pembelajaran kesopanan berbicara dalam wawancara yaitu sebesar 2470 dan di rataratakan menjadi 82,33. Untuk aspek no 1 mengenai tekanan yang dilakukan pada saat berbicara ketika wawancara jumlah nilai keseluruhan 248 dan setelah di rata-ratakan sebesar 8,26 . Nilai yang tertinggi dari no 1 yaitu 10 sebanyak 1 orang, siswa yang mendapatkan nilai sedang yaitu 9 sebanyak 10 orang, dan nilai yang paling kecil yaitu 7 sebanyak 4 orang.

Untuk aspek no 2 yaitu nada yang dilakukan pada saat berbicara ketika wawancara jumlah nilai keseluruhan yaitu 243 dan setelah di rata-ratakan sebesar 8,1. Nilai yang tertinggi dari no 2 yaitu 9 sebanyak 10 orang. Siswa yang mendapatkan nilai sedang yaitu 8 sebanyak 13 orang, dan nilai terendah yaitu 7 sebanyak 7 orang.

Untuk aspek no 3 yaitu jeda yang dilakukan pada saat berbicara ketika wawancara jumlah nilai keseluruhan sebesar 247 dan dirata-ratakan sebesar 8,23. Nilai yang tertinggi dari no 3 yaitu 9 sebanyak 10 orang. Siswa yang mendapatkan nilai sedang yaitu 8 sebanyak 17 orang, dan yang mendapatkan nilai terendah yaitu 7 sebanyak 3 orang.

Untuk aspek no 4 yaitu diksi yang digunakan pada saat berbicara ketika wawancara jumlah nilai keseluruhan sebesar 244 dan dirata-ratakan menjadi 8,13. Nilai yang tertinggi yaitu 9 sebanyak 7 orang. Siswa yang mendapatkan nilai sedang yaitu 8 sebanyak 20 orang dan yang mendapatkan nilai terendah yaitu 7 sebanyak 3 orang. 
Untuk aspek no 5 yaitu struktur kalimat yang digunakan pada saat wawancara jumlah nilai keseluruhan sebesar 247 dan dirataratakan sebesar 8,23. Nilai yang tertinggi yaitu 9 sebanyak 9. Siswa yang mendapatkan nilai sedang yaitu 8 sebanyak 19 orang dan yang mendapatkan niali terendah yaitu 7 sebanyak 2 orang.

Untuk aspek no 6 yaitu kesopanan yang dilakukan pada saat wawancara jumlah nilai keseluruhan sebesar 246 dan di rata-ratakan sebesar 8,2. Siswa yang mendapatkan nilai tertinggi yaitu sebesar 10 sebanyak 1 orang. Siswa yang mendapatkan nilai sedang yaitu 9 sebanyak 7 orang, dan yang mendapatkan niali terrendah yaitu 7 sebanyak 3 orang .

Untuk aspek no 7 yaitu sikap yang dilakukan pada saat wawancara jumlah niali keseluruhan yaitu 243 dan dirata-ratakan sebesar 8,1 . Siswa yang mendapatkan nilai tertinggi yaitu 9 sebanyak 8 orang. Siswa yang mendapatkan nilai sedang yaitu 8 sebanyak 17 orang dan yang mendapatkan nilai terendah yaitu 7 sebanyak 5 orang.

Untuk aspek no 8 yaitu pandangan yang dilakukan pada saat wawancara jumlah nilainya secara keseluruhan sebesar 248 dan dirata-ratakan sebesar 8,26. Siswa yang mendapatkan nilai tertinggi yaitu 9 sebanyak 10 orang. Siswa yang mendapatkan niali sedang yaitu 8 sebanyak 18 orang dan yang mendapatkan niali terendah yaitu 7 sebanyak 5.

Untuk aspek no 9 yaitu ketepatan sasaran yang dilakukan pada saat wawancara jumlah nilainya secara keseluruhan sebesar 248 dan dirata-ratakan sebesar 8,26. Siswa yang mendapatkan nilai tertinggi yaitu 9 sebanyak 10 orang. Siswa yang mendapatkan niali sedang yaitu 8 sebanyak 18 orang dan yang mendapatkan niali terendah yaitu 7 sebanyak 2 orang.

Untuk aspek no 10 yaitu isi wawancara jumlah nilainya secara keseluruhan sebesar 256 dan dirata-ratakan sebesar 8,53. Siswa yang mendapatkan nilai tertinggi yaitu 10 yaitu sebanyak 3. Siswa yang mendapatkan niali sedang yaitu 9 sebanyak 11 orang dan yang mendapatkan nilai terendah yaitu 7 ebanyak 1 orang.

Siswa yang memperoleh nilai paling tinggi pada tes akhir dalam kesopanan berbicara ketika melakukan wawancara dengan menggunakan strategi bermain peran yaitu 91 dengan jumlah siswa yang memperolehnya 1 orang, siswa yang memperoleh nilai 90 yaitu sebanyak 2 orang, siswa yang memperoleh nilai 89 sebanya 2 orang, siswa yang memperoleh nilai 87 sebanyak 2 orang, siswa yang memperoleh nilai 86 sebanyak 1 orang, siswa yang memperoleh nilai 85 sebanyak 3 orang, siswa yang memperoleh nilai 84 sebanyak 3 orang siswa yang memperoleh nilai 81 sebanyak 3 orang, siswa yang memperoleh nilai 80 sebanyak 1 orang, siswa yang memperoleh nilai 79 sebanyak 2 orang, siswa yang memperoleh nilai 77 sebanyak 2 orang, siswa yang memperoleh nilai 76 sebanyak 1 orang, siswa yang memperoleh nilai 75 sebanyak 2 orang, dan siswa yang memperoleh nilai 73 sebanyak 1 orang.

Dari hasil tes awal dan tes akhir selanjutnya akan dihitung perbedaannya untuk melihat perbandingan hasil yang dicapai oleh kelas tersebut. Perbandingan nilai tes awal dan tes akhir akan uji t-tes dengan statistik tes signifikan. Data hasil tes tersebut sebagai berikut.

Setelah melakukan pembelajaran menggunakan strategi bermain peran siswa mampu berbicara sopan ketika melakukan wawancara dengan benar. Dilihat dari tabel=2,83 sedangkan hitungannya $=18,29$ jadi dapat disimpulkan dalam penelitian ini sebagai berikut.

Jika $\mathrm{t}$ hitung $>$ dari $\mathrm{t}$ tabel, hipotesis diterima

Jika t hitung < dari tabel, hipotesis di tolak. 
Berdasarkan data diatas, terdapat perbedaan yang signifikan dalam kesopanan berbicara dalam wawancara sebelum dan sesudah pembelajaran maka hipotesis diterima.

\section{Pembahasan}

Efektivitas atau pengaruh yang dirasakan siswa pada saat proses pembelajaran kesopanan berbicara ketika melakukan wawancara dengan aspek yang dinilai yaitu tekanan, intonasi, nada dan jeda, diksi (pilihan kata), struktur kalimat, kesopanan dan sikap berbicara, kelancaran bahasa, pandangan, ketepatan sasaran pembicaraan, isi wawancara. Efektivitas pembelajaran tersebut dapat diketahui dengan melakukan penyebaran lembar observasi. Lembar observasi ini dimaksudkan untuk melengkapi hasil performentes sehingga tanggapan siswa dapat dijadikan sebagai acuan penggunaan strategi bermain peran dalam pembelajaran kesopanan berbicara ketika melakukan wawancara. Setelah hasil pengumpulan data diperoleh, data yang selanjutnya dapat di deskripsikan sebagai berikut:

Observasi guru dalam pembelajaran menggunakan strategi bermain peran sudah baik. Kesesuaian bahan ajar menulis kesopanan berbicara sudah bagus, merumuskan tujuan (indikator) unsur-unsur kesopanan berbicara cukup baik, pengorganisasian materi kesopanan dalam berbicara dalam wawancara, memilih metode pembelajaran strategi bermain peran, membuktikan benar tidaknya hipotesis materi kesopanan berbicara, melakukan pengamatan dengan cermat untuk membuktikan benar tidaknya hipotesis berbicara sopan dalam wawancara, membuat kesimpulan pembelajaran kesopanan berbicara dengan strategi bermain peran. Lembar observasi siswa bertujuan untuk mengetahui aktivitas siswa selama kegiatan pembelajaran.

Kemudian dari analisis lembar observasi terhadap siswa. lembar observasi siswa berisi 5 pernyataan.
Berdasarkan tabel 4.7 dapat diketahui bahwa dari 30 siswa (100\%), 95,23\% kesungguhan siswa dalam melaksanakan pembelajaran kesopanan berbicara dalam wawancara dilakukan dengan baik, dan 4,77\% kesungguhan siswa dalam melaksanakan pembelajaran kesopanan berbicara dalam wawancara dilakukan kurang baik. Berdasarkan tabel 4.7 dapat diketahui bahwa dari 30 siswa (100\%), 95,23\% Kekompakan siswa dalam mengerjakan tugas kelompok dilakukan dengan baik, dan 4,77\% kesungguhan siswa dalam melaksanakan pembelajaran kesopanan berbicara dalam wawancara dilakukan kurang baik. Berdasarkan tabel 4.7 dapat diketahui bahwa dari 30 siswa (100\%), $100 \%$ Kedisiplinan dalam pelaksanaan pembelajaran dilakukan sangat baik. Berdasarkan tabel 4.7 dapat diketahui bahwa dari 30 siswa (100\%), 71,42\% kesopanan berbicara dalam wawancara dengan strategi bermain peran dilakukan dengan cukup baik. Berdasarkan tabel 4.7 dapat diketahui bahwa dari 30 siswa (100\%), 100\% ketertiban dalam pelaksanaan pembelajaran sangat baik.

Berdasarkan hasil pengumpulan data melalui lembar penilaian performentes siswa kelas VIII B MTs Islamiyah Sayang Cianjur yang dijadikan sebagai sampel, diperoleh data kemampuan siswa dalam pemebelajran kesopaan berbicara dalam wawancara yang berbeda-beda mulai dari nilai terendah 73 sampai yang tertinggi 91. Nilai tersebut diperoleh dari aspek yang dinilai yaitu aspek tekanan, intonasi, nada dan jeda, diksi (pilihan kata), struktur kalimat, kesopanan dan sikap berbicara, kelancaran bahasa, pandangan, ketepatan sasaran pembicaraan, isi wawancara.

Berdasarkan data hasil performen tes yang dilakukan oleh siswa, diketahui bahwa nilai rata-rata kemampuan siswa dalam kesopanan berbicara dalam wawancara yaitu $82,33 \%$. Apabila dihubungkan pada tabel penentuan patokan persentase katagori nilai maka rata-rata nilai tersebut termasuk dalam kategori baik karena berada pada persentase 76\%-85\% dengan keterangan baik. Hal ini 
berarti kemapuan siswa kelas VIII B MTs Islamiyah Sayang sudah baik dalam pembelajaran kesopaann berbicara dalam wawancara dengan menggunakan strategi bermain peran. Peneliti hanya membahas mengenai aspek tekanan, intonasi, nada dan jeda, diksi (pilihan kata), struktur kalimat, kesopanan dan sikap berbicara, kelancaran bahasa, pandangan, ketepatan sasaran pembicaraan, isi wawancara.

\section{SIMPULAN}

Proses pembelajaran kesopanan berbicara dalam wawancara dengan strategi bermain peran sangat baik diterapkan pada pembelajaran kesopanan berbicara dalam wawancara, karena pendekatan pembelajaran strategi bermain peran tidak hanya memandang hasil belajar sebagai muara akhir, namum proses pembelajaran dipandang sangat penting. Oleh karena itu, pembelajaran strategi bermain peran menekankan pada keterampilan proses.

Strategi bermain peran dapat meningkatkan kesopanan berbicara siswa kelas VIII B MTs Islamiyah Sayang Cianjur. Berdasarkan hasil pretes (tes awal) dengan nilai rata-rata $61,76 \%$ dan hasil postes (tes akhir) $82,33 \%$, jadi dapat disimpulkan bahwa

\section{DAFTAR PUSTAKA}

Fathoni, Abdurahmat. 2006. Metodologi Penelitian dan Teknik Penyusunan Skripsi. Jakarta: Rineka Cipta.

Nadar. 2009. Kesantunan dalam Berbahasa. Jakarta: Buana Karya.

Tarigan, Henry Guntur. 2008. Berbicara Sebagai Suatu Keterampilan. Bandung:Angkasa 